\title{
Laboratory Evaluation for Integrative and Functional Medicine and Some Pathophysiology Aspect of Assesstment of Asymptomatic Renal Dysfunction in Patients with Untreated Seropositive Rheumatoid Arthritis. Is a difference between Seropositive and Negative Arthropathy?
}

\author{
Spasovski Dejan* \\ Ss Cyryl and Methodius University of Skopje, Republic of Macedonia
}

Submission: December 13, 2016; Published: January 26, 2017

*Corresponding author: Spasovski Dejan, University Clinic of Rheumatology, "Ss Cyril and Methodius” University, Skopje, Republic of Macedonia, Tel: +389023147-668; Email: drspasovski@yahoo.co.uk

\section{Abstract}

Aim: To estimate the effect of initial therapy with paracetamol and ketoprofen on glomerular and tubular integrity in patients with Rheumatoid arthritis (RA), to quantify toxicity of these drugs through measurements of the enzyme excretion that correlates with the damage degree on the tubular epithelium. Microalbuminuria is used as marker for glomerular damage, and the urinary excretion of N-Acetyl- $\beta$-Dglucozaminidase (NAG) as an indicator of proximal tubular damage. To determine if there is a change in the clinical indicators do renal function (serum urea and creatinine, urine urea and creatinine, glomerular filtration rate - GFR) in the course of disease and if that change correlates with the dynamics of the quantity of excreted enzymes in urine, reactants of the acute pages and index of disease activity (DAS28).

Methods: Using the colorimetric method for determination of NAG, as well as immunoturbidimetric assay for detection of microalbuminuria, we examined samples of 70 participants (35 RA pts treated only with Paracetamol, 35 RA pts treated with Ketoprofen), followed up in five time intervals in the course of 24 weeks. Rheumatoid factor (RF) is determined with the agglutination test (Lateks RF test) in the same participants.

Results: there is a weak correlation between NAG and microalbuminuria ( $\mathrm{r}=0.16)$ in the group of patients treated with Paracetamol, while in the group treated with Ketoprofen there is moderate correlation ( $\mathrm{r}=0.28)$. NAG enzymuria in range, in number of examined patients and in time of appearance is greater and appears earlier in the group with Ketoprofen compared with the group of Paracetamol.

Conclusion: Ketoprofen is more potent NAG inductor and triggers greater tubular enzymuria than Parcetamol.

Keywords: N-acetyl- $\beta$-D-glucosaminidase; Microalbumin; Rheumathoid arthritis; Paracetamol; Ketoprofen

Abbreviations: RA: Rheumatoid Arthritis; NAG: N-Acetyl- $\beta$-D-Glucozaminidase; GFR: Glomerular Filtration Rate; ARA: American Association for Rheumatism

\section{Introduction}

The use of drugs in the treatment of Rheumatoid arthritis (RA) aims to shorten disease duration and prevent complications. Treatment with basic drugs somehow fulfils the expectations. There are a lot of findings recently which show that drugs can damage certain organs caused by their toxic effect due to their accumulation in the organs. A lot of experiments were realized in the previous two decades aiming to follow the toxic effect of pharmacotherapy to kidneys. These results are used as a base to follow up the influence of drugs in different kidney diseases. In these experiments, beside immunologic, radiologic and cytologic analyses, an important role play also biochemical analyses for detection of certain pathologic conditions caused in the course of treatment.

Among them, determination of enzymes' and their isoenzymes' activity in the seum, urine and renal tissue has an important role. Very often, therapeutic drugs (NSAIDs, Drugs that modify 
disease activity - DMRADs, Paracetamol, immunosupressive and cytotoxic drugs), can have some nephrotoxic effect. The drug dose very often is not adjusted according to the patient's condition that can cause some unwanted effects, especially those related to kidney failure due to the their kidney accumulation. This can be seen in long term RA therapy. Experiments done so far show that there is no indicator, traser or marker that reveals on time the nephrotoxicity caused in the course of disease. Efforts are made to detect these secondary (unwanted) effects by analysis of certain enzyme's activity in the urine.

\section{Diagnostic and prognostic significance of biotracers}

In the contemporary medicine there is a tendency to find the most specific and most sensitive biomarkers as disease indicators and diagnostic tools for follow up of successful treatment. A lot of investigation has been made in order to choose potential biomarkers that would be important in the clinical practice, giving the best diagnostic information. Especially important were their analytical and clinical application and their cost-benefit. Useful biomarker has to fulfil some criteria:

A. To have relatively high tissue-specific concentration, and low concentration in other tissues.

B. To be adeqatly distributed subcellularly, so, after the cell damage to be found easily in the examined fluid.

C. To be constant long enough in order to be suitable for following its concentration.

D. To be able to be detected with sensitive analytical methods.

E. To be determined the cut-off values, taking in consideration clinical sensitivity and specificity.

\section{Renal markers for estimation of renal disfunction}

Urine enzymes could originate from plasma, lymph nodes of urinary tract, epithelial cells of the urinary tract, white blood cells, red blood cells and kidneys. There are about 40 diffent enzymes belonging to different groups: oxidoreductases, transferases, hydrolases, lyases. Only isomerases and ligases are not found in urine. Such great amount of enzymes in the urine shows the dominant role of the kidney in their exretion. Several classes of measurable proteins in urine are used for estimation of the nephrotoxicity.

a) Enzyme with high molecular weight, that is not usually filtrated in the glomerul, originating from the proximal tubul (microsomal AAP, NAG, $\gamma$-GT)

b) Intermediary proteins that are usually filtrated in the glomerul in very small amounts are reapsorbed in the tubuls in a great amount (microalbumine, transferin).

c) Low moleculare weight proteins that are normaly filtered in the glomerul and are reapsorbed in the tubuls $(\beta 2$ microglobulin).
According to their subcellular location these enzymes could be devided in membranous (AAP, $\gamma$-GT,AF), lysosomal (NAG, $\beta$-GLU, $\beta$-GAL, lyzozyme), mitohondrial (MDH, $\gamma$-LDH), cytoplasmal (LDH). With the development of hystochemistry a detailed insight was made in the enzyme distribution in different nephron structures. Their presence is lower in glomerules than in tubules. The specific enzyme distribution in the nephron enables detection of the spot that is damaged as a sequel of nephrotoxic agents. Examination of the cell membranes of the brush epithelium of the proximal tubules prove the localisation of the alanine amino peptidase (AAP) in 90\%, Alkaline phosphatase (AP) in $70 \%$ and $\gamma$-glutamyl transpeptidase $(\gamma$-GT) in $50 \%$ of the whole enzyme activity in the kidney. The examinations reveal that tubular part of the nephrone is rich with enzymes. Brush border is very sensitive in changes in their physiological status, so the release of the superficial enzymes could be used as a marker in primary and secondary renal impairments due to different drugs and toxins $[1,2]$.

All the urinary enzymes, U-NAG (urinary) are the most examined. It is the enzyme which belongs to the class of hydrolysis present in a great amount in the lysosomes in the proximal tubular cells. In the human body and biological fluids there are two major enzyme forms: A (Acid) i B (Basic) [3-5]. The percentage of a isoform (U-NAG-A) is the greatest in the normal urine $[6,7]$. At the end of the cell maturational process it is found in soluble form in the citosol. That's why its exretion is connected with the exfoliative turnover and is noted as functional enzymuria. B isoform (U-NAG-B) depends on the maturation and is closely connected with the basal membrane in which it is present. Due to this location of B isoform (U-NAG-B), it is massively released in the tubular lumen only in the case of cytolytic tubular lesion. Its presence in the urine correlates with the cell lysis and is marked as lesion enzymuria [8,9]. NAG could be detected also in the circulation. But, plasma NAG could not pass over intact glomerular membrane because of its high molecular weight (140.000 Daltons). For that reason, in healthy individuals the urinary NAG is result of the enzyme amount released from the renal tubular cells [10] and is very sensitive marker for renal tubular damage [11-14].

\section{Urine albumin (Microalbuminuria)}

Albumin (molecular weight-66 KDa) is quantitatively the most important plasma and urine protein. Approximately $30 \%$ of urine proteins belong to albumin, and it is good indicator for estimation of the changes in glomerular permeability. Such changes happen in patients with diabetic and hypertensive nephropathy, nephritic syndrome, preeclampsia and glomerulonephritis. Urine albumin excretion has high individual variability and depends on the physical activity and food variations. From pathophysiological point of view microalbuminuria could be caused by the increased glomerular permeability for albumin, increased glomerular pressure and/or decreased tubular albumin reabsorption. Renal endothelium is intimately involved in the regulation of these processes $[15,16]$. 


\section{Renal impairment due to use of paracetamol and ketoprofen}

If drug is transported in proximal tubules via pinocytosis, than the hypothesis that nephrotoxicity is caused by lysosomal disfunction due to the drug precipitation in lysosomes is proved. Vacuols fulfilled with proteins are transported in the middle part of the cell, where they are unite with the existing lysosomes. Hydroltic enzymes catabolize it and the new products are suitable for recirculation.

\section{In the mechanism of Methotraxate nephrotoxicity two moments are very important:}

a) Active secretion in proximal tubules with the same degree of reapsorption

b) Active transport inside the proximal tubules in the antiluminal side with restricted movement of tubular fluids. It is proved that the toxic agent can pass through cell membranes, entering in lysosomes in non-ionised form, so it is trapped in these organels due to the low $\mathrm{pH}$.

Possible mechanism of nephrotoxicity culd be due to interference of the normal lysosomal digestion which leads to lysis of the lysosomal membrane, and tranfer of the acid hydrolazes in the cell cytosol of the proximal tubules, which is manifested latter with necroses.

\section{As possible pathways for entrance in the epithelial cells are noted:}

A. Apical membrane transportation via pinocytosis with adequate drug

uptake (chemotherapeutics, aminoglicosides, cephalosporins, diuretics i other toxic drugs) inside the lysosomes.

B. Apical membrane transportation via some unknown way which complements the process of pinocytosis.

C. Basolateral membrane transportation.

\section{Material and Methods}

The diagnosis of the patients included in the study is based on the revised diagnostic criteria for classification of Rheumatoid arthritis proposed in 1987 by the American Association for Rheumatism (ARA) [17]. In order to include the patient in the group with RA, he should fulfill at least 4 of the 7 criteria. Criteria 1-4 should persist at least 6 months. In the study are included 35 patients with RA (20 women, 15 men), treated with Paracetamol, and 35 patients with RA (22 women, 13 men) treated with Ketoprofen. Their average age is 55,53 years $( \pm 8,42)$ range $(40$ 65 years), in the group treated with Paracetamol, while 53,24 years $( \pm 10,36)$ range $(29-65$ years $)$ in the group treated with Ketoprofen. Mean disease duration from the begining is 40,11 months $( \pm 40,23$ months), range (1-168 months). None of the patients has previous or current hystory of renal disease. None of the patients previously used NSAIDs. Other patients negated use of other drugs such as golden salts, antibiotics or diuretics. Specimens are collected in the period of 2 years.

\section{Inclusion criteria}

In the study are included patients with RA, aged 18-65 years, not previously treated with NSAIDs or DMARDs.

\section{Exclusion criteria}

From the study are excluded patients with diseases or conditions that could influence results directly or indirectly

a. Patient younger than 18 years.

b. Patients with previous history of disease of the spleen, thyroid gland, liver, kidneys, hematological, cardiovascular, neurological, autoimmune and lung diseases.

c. Patients with diabetes mellitus, febrile conditions, acute infections, neoplasms.

d. Patients with uric arthritis, SLE, mixed connective tissue disese, vasculitis.

e. Patients with history of blood transfusion and patients with body overweight.

f. Patients with history of use of drugs from the base line.

g. Patients that in 0 point had increase level of glucose, serum ind urine urea and creatinine, blood hypertension, smokers and blood and enzyme disorders

h. Patients previously treated with salycilates, antibiotics, golden salts or diuretics

i. All the patients took part in this study voluntarily, so the ethic criteria for this study are fulfuled.

\section{Clinical estimation of disease activity}

Clinical estimation is made by subspecialist in the fild. Disease activity is estimated using DAS 28 index (Disease Activity Score DAS 28) [18-20]. The index uses mathematical formula to obtain unique composite quantitative score, which consists of palpabile painful joints (maximal niumber 28), swallen joints (maximal niumber 28), Erythrocyte sedimentation rate (ESR) and patient's estimation for disease activity $(0-100 \mathrm{~mm})$. Visual Analogue Scale - VAS) and morning stiffness (minutes). DAS 28 index ranges from 0 to 10 and score $<3.2$ qualifies the disease as low active.

\section{Laboratory estimation}

For clinical estimation of the disease it is necessary to examine following laboratory variables: complete blood count and differential, reactants of the acute phase, ACPA-antibodies, C-reactive protein (CRP), Rheumatoid factor ( RF) and Erythrocyte sedimentation rate (ESR), alcaline phosphatase (AP), aspartat aminotransferase (AST), alanin aminotransferase (ALT), creatin kinase (CK), laktat dehydrogenase (LDH), serum urea, serum creatinin. Urine samples are taken not only for rutine analyses, but also for determination of NAG and microalbuminuria. 


\section{Detection of microalbuminuria with immunoturbidimetric assay (randox laboratories limited)}

Principles: Undissolved sample is added to the puffer with antibodies specific for human serum albumin. The absorbance (340nm) is proportional with the albumin concentration in the urine sample. With the construction of the standard curve from the standard absorbance, one can determine the albumin concentration in the sample. Determination is automatically with the use of DAKO tests.

Urine sample and its storage: The middle stream from the morning urination is taken. It is centrifuged before the use in order to use purified supernatant.

Referent values: microalbuminuria 2.0-20.0 mg/L.

\section{Determination of theactivity of $\mathrm{N}$-acetyl- $\beta$-D-glucosaminidase (NAG): colorimetric assay (roche)}

Principles: Cresolsulfonphthaleinyl-N-acetyl- $\beta$-D-glucosaminide as sodium salt is hydrolyzed from NAG releasing 3-cresolsulfonephthalein, sodium salt (3-cresol purple) which is measured photometrically on 580nm wavelength (Roche Mancheim tests). The examined urine is centrifuged and the supernatant is taken.

Referent values: NAG in urine $0.27-1.18 \mathrm{U} / \mathrm{mmol}$ creatinine Serum urea is determined with the method «Kassirer». Referent values: serum urea $3-7,8 \mathrm{mmol} / \mathrm{L}$ Serum creatinin is determined with the method «Jaffe». Referent values: serum creatinine 45-109 $\mu \mathrm{mol} / \mathrm{L}$; urine creatinine $7-17 \mu \mathrm{mol} / \mathrm{dU}$. C-reaktiven protein (CRP) is determined with the agglutination assay (Lateks CRP test)(Bio Systems S.A. Reagents \& Instruments Costa Brava 30, Barcelona, Spain). Referent values $<6 \mathrm{mg} / \mathrm{L}$ CRP in serum rheumatoid factor (RF) is determined with the agglutination assay (Lateks RF test) (Bio Systems S.A. Reagents \& Instruments Costa Brava 30, Barcelona, Spain). Referent values $<8 \mathrm{IU} / \mathrm{ml}$ in serum. For determination of the Erythrocyte sedimentation rate (ESR) is used quantitative method - Westergren test. Referent values are for men 7-8mm, for women 11-16mm.

\section{Statistical Analysis}

To test the significance of the differences between two aritmetical means i.e.proportions is used the Student t-test. To compare the mean values of certain numerical parameters between two groups was used Wilcox on-matched test for independent species. Sensitivity and productivity for positive and negative test of the examined markers is determined with the sensitivity and specificity test. P-value between 0.05 and 0.1 is considered statistically significant. Data analysis is performed with statistical package Statistic 7.0.

\section{Results}

Analyzing the group of patients treated with Paracetamol in comparison with the distribution of patients according to NAG values in the four samples, one can conclude that NAG values are registered in 20 patients in the 12 th week, when the degree of the mean urine NAG value is highest $(1.20 \pm 1.04)$ ( Table 1$)$. Analyzing the group of patients treated with Paracetamol in comparison with the distribution of patients according to NAG values in the four samples, one can conclude that NAG values are registered in 26 patients in the 12th week, when the degree of the mean urine NAG value is highest $(1.80 \pm 0.33)$. Testing the significance of the differences in both groups in the 0 (zero) sample in the group of patients treated with paracetamol, the mean value of the NAG enzymuria is in range $0.93 \pm 0.48$, while in the group of patients treated with Ketoprofen is $1.59 \pm 0.67$. That shows that ketoprofen is more potent NAG indicator in comparison with Paracetamol both in range and in time of appearance. In the group of patients treated with Paracetamol, about the distribution of patients according to the values of microalbuminuria in the four groups, one can conclude that increased values of microalbuminuria are registered in 5 patients in the 4 th week, when the degree of microalbuminuria is highest 14.1 \pm 1.07 .

Table 1: NAG, microalbuminuria in the group of patients with paracetamol and ketoprofen.

\begin{tabular}{|c|c|c|c|c|}
\hline \multicolumn{3}{|c|}{ Group Paracetamol N=35 } & \multicolumn{2}{c|}{ Group Ketoprofen N=35 } \\
\hline & $\begin{array}{c}* \mathrm{NAG}+>1.18(\mathrm{U} / \mathrm{mmol} / \\
\text { crea) value }(\mathrm{M} \pm \mathrm{SD})\end{array}$ & $\begin{array}{c}\text { Microalbuminuria }+>20 \\
(\mathrm{mg} / \mathrm{L})\end{array}$ & $\begin{array}{c}\text { NAG }+>1.18(\mathrm{U} / \mathrm{mmol} / \\
\text { crea) value (M } \pm \text { SD) }\end{array}$ & $\begin{array}{c}\mathrm{M}+>20(\mathrm{mg} / \mathrm{L}) \text { value (M } \\
\pm \mathrm{SD})\end{array}$ \\
\hline 0 & $1.13 \pm 0.54$ & $12.91 \pm 10.07$ & $0.93 \pm 0.48$ & $16.35 \pm 7.41$ \\
\hline time & 13 & 5 & $1.27 \pm 0.47$ & $18.80 \pm 0.33$ \\
\hline 4 & $1.17 \pm 0.48$ & $14.1 \pm 1.07$ & 18 & 7 \\
\hline weeks & 18 & 5 & $1.58 \pm 1.40$ & $16.50 \pm 9.69$ \\
\hline 8 & $1.19 \pm 0.67$ & $11.91 \pm 11.23$ & 23 & 4 \\
\hline weeks & 19 & 4 & $1.80 \pm 0.33$ & $15.50 \pm 8.58$ \\
\hline 12 & $1.20 \pm 1.04$ & $12.08 \pm 10.68$ & 26 & 2 \\
\hline weeks & 20 & 2 & & 2 \\
\hline
\end{tabular}

*NAG-positive value (>1.18 U/mmol/crea); Microalbuminuria- positive value (>20mg/L)

${ }^{* *}$ Data are expressed as mean values $\mathrm{M} \pm \mathrm{SD}$ and as number of patients with values in normal range or above normal. 


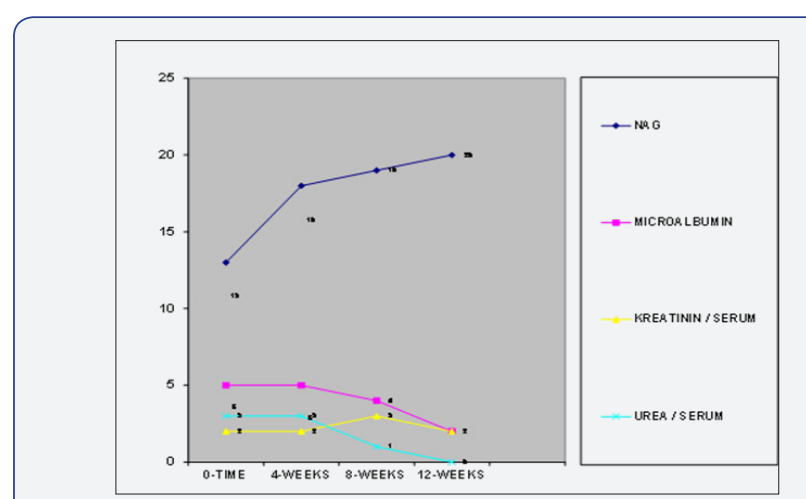

Figure 1: Distribution of patients in the group with paracetamol according to the increased values of NAG, microalbuminuria and other laboratory variables in the four samples.
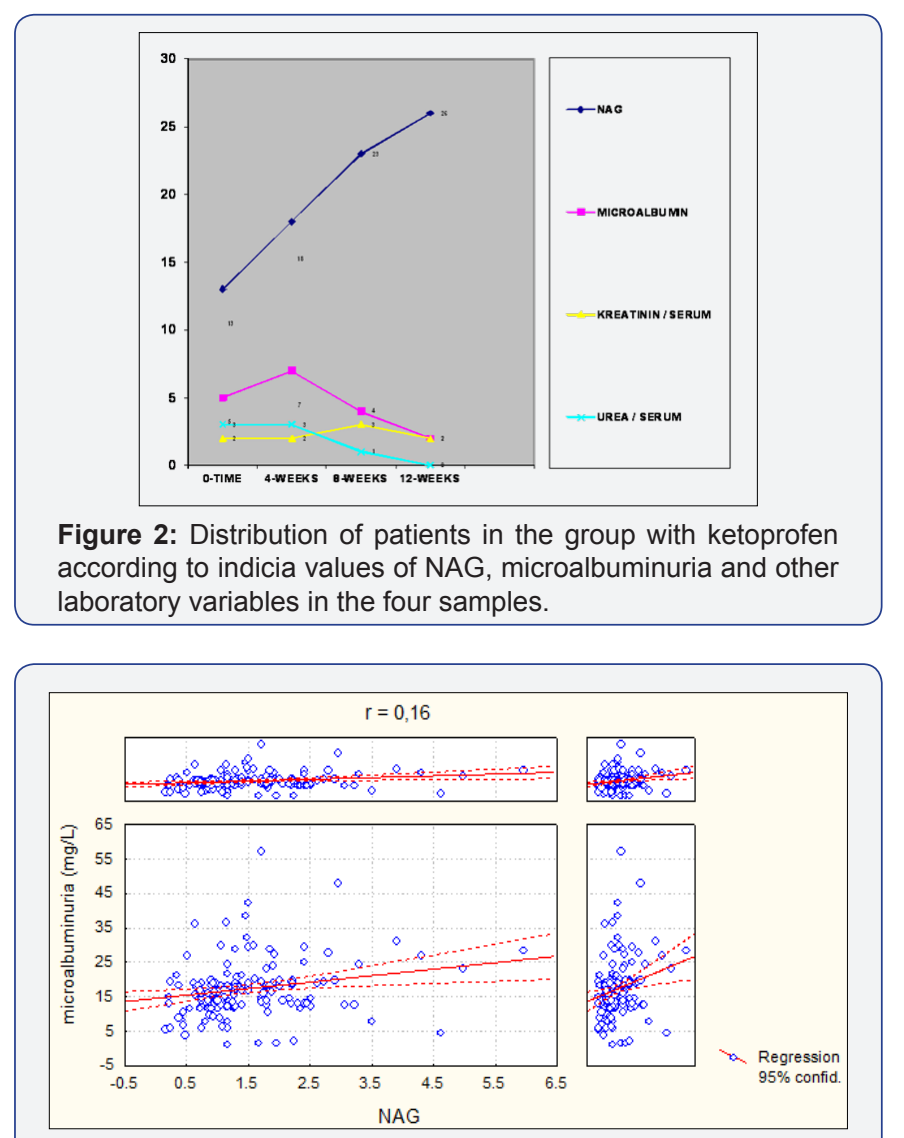

Figure 3: Pearson's coeficient of correlation $(r)$ between the values of NAG and microalbuminuria in the group treated with Paracetamol. There is weak correlation between NAG and microalbuminuria $(r=0,16)$.

Analyzing the distribution of patients according to the values of microalbuminuria in the four samples, in the group of patients treated with Ketoprofen, one can conclude that in 7 patients in the 4 th week, when the degree of microalbuminuria is highest $18.80 \pm 0.33$ (Figure 1). Testing the significance of the differences in both examined groups in the zero samples, in the group of patients treated with Paracetamol, mean value of microalbuminuria is in range $0.53 \pm 0.48$, while in the group of patients treated with Ketoprofen is $0.67 \pm 0.57$. That explains that Paracetamol has identical values of microalbuminuria in comparison with Ketoprofen (Figure 2). Analysis with the persons c2 test shows that there is moderate correlation between NAG and microalbuminuria $(r=0.28)$ between the increase of the values of NAG and microalbuminuria in the four samples in the follow up period of 12 weeks in the group of patients treated only with Ketoprofen (Figure 3).

Analysis with the persons $\mathrm{c} 2$ test shows that there is statistical significant correlation $(r=0.16)$ between the increase of the values of NAG and microalbuminuria in the four samples in the follow up period of 12 weeks in the group of patients treated only with Paracetamol.

\section{Discussion}

Traditional treatment of RA includes non-steroid antiinflammatory drugs (NSAIDs), drugs that modify the disease (DMARDs), steroids, immunosuppressive and cytotoxic drugs. Metotrexate in low dose regimen is the most frequent drug from the group of DMARDs, while from the group of NSADs the most used drugs are Ketoprofen (NiflamR, KetonalR), as well as Paracetamol. The approach for estimation of the drug nephrotoxicity is possible only with drugs that have dominant proximal tubular excretion, such as Metotrexate, Ketoprofen, Paracetamol and golden salts). Such approach for estimation of the drug nephrotoxicity is not applicable for other drugs from the base line used in the treatment of RA, such as resochin, sulphasalazine and leflunomide, due to the predominant hepatobiliar secretion. There are not data in the literature to the toxic effect of these drugs on proximal tubular dysfunction. In untreated RA primarily is affected tubular and much less glomerular function [21]. Glomerular integrity is basically intact in the examined groups of RA patients with the use of Paracetamol and Ketoprofen. The initial increase in the activity is the result of the changes in cell synthesis and not always enzymuria could be the result of the lytic or necrotic processes.

Paracetamol usually does not trigger significant damage of the renal proximal tubules in most of the examined patients. Nephrotoxicity of Ketoprofen is higher in comparison with Paracetamol. Ketoprofen is more potent NAG inductor in comparison with Paracetamol. NAG induction is higher and appears earlier in the use of Ketoprofen in comparison with Paracetamol. These results correspond with the findings in the literure [22-26]. Early detection of the increased NAG enzymuria or appearance of the microalbuminuria before the beginning of the drug use could be useful compared with the possible toxicity probably related with impared renal clearance. There is not any change in the clinical indicators of the renal function compared with the degradational products of the nitrogen metabolism (serum creatinin, serum urea) in the course of disese. The least sensitive markers for early nephrotoxicity caused by Ketoprofen and Paracetamolot are the serum creatinin and urea concentration, as well as the level of calculated creatinin clearance. These tests point out the changed, decreased glomerular filtration, but not 
changes in the renal tubular function. We think that the use of these parameters could be applicable in the clinical practise in cases with long term therapy with Ketoprofen, Metotrexate and Paracetamol combined with antibiotic therapy, when they can show impairment of the gromerular filtration.

\section{Conclusion}

Results obtained in our study proved the safety of Paracetamolot and Ketoprofenot in the treatment of RA patients. As measures taken for prevention of nephrotoxicity are: follow up of the renal function by regular check up of the enzyme activity in the urine, estimation of the effectivness of the exfoliative turn over on tubular cells, avoidance of frequent use of drugs and individual adjustment of the drug dosage. As complementary diagnostic tools determination of the urine NAG together with urinary creatinin excretion could be more sensitive tests for renal damage in patients with RA.

\section{References}

1. Moriguchi J, Ezaki T, Tsukahara T, Furuki K, Fukui Y, et al. (2003) Comparative evaluation of four urinary tubular dysfunction markers, with special references to the effects of aging and correction for creatinine concentration. Toxicol Lett 143(3): 279-290.

2. Banday AA, Farooq N, Priyamvada S, Yusufi AN, Khan F (2008) Time dependent effects of gentamicin on the enzymes of carbohydrate metabolism, brush border membrane and oxidative stress in rat kidney tissues. Life Sci 82(9-10): 450-459.

3. Neufeld EF (1989) Natural history and inherited disorders of a lysosomal enzyme, b hexosaminidase. J Biol Chem 264(19): 1092710930.

4. Robinson D, Stirling JL (1968) N-Acetylglucosaminidase in human spleen. Biochem J 107(3): 321-327.

5. Price RG, Dance N (1972) The demonstration of multiple heat stable forms of N-acetyl-b glucosaminidase in human serum. Biochim Biophys Acta 271(1): 145-153.

6. Lockwood TD, Bosmann HB (1979) The use of N-acetylglucosaminidase in human renal toxicology. I. Partial biochemical Characterization and excretion in human and release from the isolated rat kidney. Toxicol Appl Pharmacol 49(2): 323-336.

7. Gibey R, Dupond JL, Henry JC (1984) Urinary N-acetyl-Dglucosaminidase isoenzyme profile: a tool for evaluating nephrotoxicity of aminoglycosides and cephalosporins. Clin Chim Acta 137(1): 1-11.

8. Paigen K, Peterson J (1978) Coordinacy of lysosomal enzyme excretion in human urine. J Clin Invest 61(3): 751-762.

9. Bourbouze R, Bernard M, Baumann FCh, Perez-Gonzales N, MartinBarientos J, et al. (1984) Subcellular distribution of the N-acetyl-b-Dglucosaminidase isoenzymes from rabbit kidney cortex. Cell Mol Biol 30(1): 67-74.

10. Burton CJ, Walls J (1994) Proximal tubular cell, proteinuria and tubulointerstitial scarring. Nephron 68(3): 287-293.

11. Chiu JSP (1994) Models used to asses renal function. Drug Devel Res 32(4): 247-55.
12. Price RG (1992) Measurement of N-acetyl- $\beta$-glucosaminidase and its isoenzymes in urine, methods and clinical applications. Eur J Clin Chem Clin Biochem 30(10): 693-705.

13. Price RG (1992) The role of NAG ( $N$-acetyl- $\beta$-D-glucosaminidase) in the diagnosis of kidney disease including the monitoring of nephrotoxicity. Clin Nephrol 38(Suppl1): 14-19.

14. Tucker SM, Pierce RJ, Price RG (1980) Characterization of human $\mathrm{N}$-acetyl- $\beta$-D glicosaminidase isoenzymes as an indicator of tissue damage in disease. Clin Chim Acta 102(1): 29-40.

15. Mogensen CE, Chachati A, Christensen CK, Close CF, Deckert T, et al. (1986) Microalbuminuria: an early marker of renal involvement in diabetes. Uremia Invest 9(2): 85-95.

16. Rowe DJ, Dawnay A, Watts GF (1990) Microalbuminuria in diabetes mellitus: review and recommendations for the measurment of albumin in urine. Ann Clin Biochem 27(4): 297-312.

17. Van Gestel AM, Prevoo ML, van't Hof MA, van Rijswijk MH, van de Putte LB (1996) Development and validation of the European league against rheumatism response criteria for rheumatoid arthritis. Comparison with the preliminary American college of rheumatology and the world health organization/international league against rheumatism criteria. Arthritis Rheum 39(1): 34-40.

18. Prevoo ML, van't Hof MA, Kuper HH, van Leeuwen MA, et al. (1995) Modified disease activity scores that include twenty-eight-joint counts. Development and validation in a prospective longitudinal study of patients with rheumatoid arthritis. Arthritis Rheum 38(1): 44-48.

19. Balsa A, Carmona L, Gonzalez-Alvaro I, Belmonte MA, Tena X, et al. (2004) Value of DAS-28 and DAS 28-3 as compared to ACR-defined remission in rheumatoid arthritis. J Rheumatol 31(1): 40-46.

20. Prevoo ML, van Gestel AM, van T Hof MA, van Rijswijk MH, van de Putte LB, et al. (1996) Remission in a prospective study of patients with rheumatoid arthritis. American rheumatism association preliminary remission criteria in relation to the disease activity score. Br J Rheumatol 35(11): 1101-1105.

21. Dejan Spasovski, Todor Gruev, Nada Marina, Jordan Calovski, Snežana Percinkova, et al. (2007) The Diagnostic Value of N-Acetyl- $\beta$-DGlucosaminidase and Microalbumin Concentrations in Rheumatoid Arthritis. JMB 2(4)6: 300-308.

22. Boers M, Dijkmans BA, Breedveld FC, Camps JA, Chang PC, et al. (1990) Subclinical renal dysfunction in rheumatoid arthritis. Arthritis Rheum 33(1): 95-101.

23. Knudsen LS, Klarlund M, Skjødt H, Jensen T, Ostergaard M, et al. (2008) Biomarkers of inflammation in patients with unclassified polyarthritis and early rheumatoid arthritis. Relationship to disease activity and radiographic outcome. J Rheumatol 35(7): 1277-1287.

24. Koseki Y, Terai C, Moriguchi M, Uesato M, Kamatani N (2001) A prospective study of renal disease in patients with early rheumatoid arthritis. Ann Rheum Dis 60(4): 327-231.

25. Marchewka Z, Przewłocki M, Lepka M, Długosz A, Kochman K (2006) Selected biochemical parameters of urine in the evaluation of paracetamol nephrotoxicity. Przegl Lek 63(12): 1299-1303.

26. Da Silva Melo DA, Saciura VC, Poloni JA, Oliveira CS, Filho JC, et al. (2006) Evaluation of renal enzymuria and cellular excretion as an marker of acute nephrotoxicity due to an overdose of paracetamol. Clin Chim Acta 373(1-2): 88-91. 
- Quality Editorial service

- Swift Peer Review

- Reprints availability

- E-prints Service

- Manuscript Podcast for convenient understanding

- Global attainment for your research

- Manuscript accessibility in different formats

( Pdf, E-pub, Full Text, Audio)

- Unceasing customer service

Track the below URL for one-step submission https://juniperpublishers.com/online-submission.php 